\title{
Effect of Feeding Graded Levels of Acid Soaked Cajanus cajan Seed on Carcass Characteristics and Organ Weight Changes of Broiler Finisher
}

\author{
H. O. Amusa1 ${ }^{*}$, S. D. Ogungbenro ${ }^{1}$, T. D. Makanju ${ }^{1}$, 0. 0. Okunlola1 ${ }^{1}$, T. M. Adeoti², T. A. Oseni' ${ }^{1}$, \\ I. A. Adebisi' ${ }^{1}$, F. L. Amusa ${ }^{3}$ \\ ${ }^{1}$ Department of Animal Health and Production Technology, Faculty of Animal and Fisheries Technology, Oyo State College of \\ Agriculture and Technology, Igbo-Ora, Nigeria \\ ${ }^{2}$ Department of Animal Health and Production Technology, School of Science, Oke-Ogun Polytechnic Saki, Oyo State, Nigeria \\ ${ }^{3}$ Department of Pure and Applied Chemistry, Ladoke Akintola University of Technology, Ogbomoso, Nigeria \\ Email: ^hammed4dtop@yahoo.com
}

How to cite this paper: Amusa, H.O., Ogungbenro, S.D., Makanju, T.D., Okunlola, O.O., Adeoti, T.M., Oseni, T.A., Adebisi, I.A. and Amusa, F.L. (2021) Effect of Feeding Graded Levels of Acid Soaked Cajanus cajan Seed on Carcass Characteristics and Organ Weight Changes of Broiler Finisher. Open Access Library Journal, 8: e7072. https://doi.org/10.4236/oalib.1107072

Received: December 9, 2020

Accepted: May 23, 2021

Published: May 26, 2021

Copyright $\odot 2021$ by author(s) and Open Access Library Inc.

This work is licensed under the Creative Commons Attribution International License (CC BY 4.0).

http://creativecommons.org/licenses/by/4.0/ (c) (i) Open Access

\begin{abstract}
A total of (90) day old broilers were used for the study to determine the carcass characteristics and organ weight changes of broiler finisher fed graded levels of acid soaked Cajanus cajan seed meal diet. The birds were randomly assigned into 3 dietary treatments of 30 birds consisting of 3 replicates of (10) birds per replicates in a completely randomized design experiment. The seeds used were purchased from Towobowo market in Igboora. The raw pigeon pea seeds were pre-treated by soaking at the rate of $1 \mathrm{~kg} / 3 \mathrm{~L}$ of water for 12 hours after which the soaked seeds were soaked at the rate of $1 \mathrm{~kg} / 3 \mathrm{~L}$ of raw pap water filtrate for 24 hours, initial and final $\mathrm{pH}$ was taken. The sample was sundried for 3 days, milled and then included in the diet accordingly. Birds on $\mathrm{T} 1$ received the control diet, $\mathrm{T} 2$ received $10 \%$ level of processed pigeon pea, while T3 received $20 \%$ level of processed pigeon pea. The experiment lasted for eight weeks. At the end of the 8 weeks feeding trial, three (3) birds per treatment were sacrificed for carcass analysis and internal organs were harvested to determine the weight changes in the internal organs. Results showed that there was significant $(\mathrm{P}>0.05)$ difference in the live weight, dress weight, plugged weight, dressing percentage, neck, wing, breast muscle, thigh, drum stick and shank. However, there was no significant $(\mathrm{P}<0.05)$ difference in the value recorded for head and back. Birds on T2 recorded the highest value of live weight (2850.50 g), dress weight (2565\%), plucked weight (285.50\%), neck (5.00\%), back (11.59\%) while the lowest value of live weight was recorded for birds on T1 (2481.50 g), dress weight (2285\%), plucked weight (196.50\%), back (11.10\%). Birds on T1 recorded the highest value of
\end{abstract}


thigh $(10.69 \%)$, drum stick (10.94\%) and shank (5.14\%) while birds on T3 recorded the lowest value of thigh (10.04\%) and drum stick (10.59\%) with birds on T2 recording the lowest value of shank (4.44\%). For internal organs however, result showed that there were significant differences $(P>0.05)$ in liver, lungs, spleen, kidney, bile, GIT weight, open gizzard, empty gizzard, Proventriculus and GIT length and there was no significant $(\mathrm{P}<0.05)$ difference in live weight and heart. Birds on T2 had the highest value of liver (2.15\%), lungs (0.56\%), GIT weight $(4.72 \%)$ and GIT length $(5.53 \%)$ while birds on T3 had the lowest value of liver (1.84\%), lungs $(0.37 \%)$, GIT weight $(4.01 \%)$. It can be concluded that pigeon pea soaked in acidic medium can be fed to birds without having any negative effect on carcass characteristics and organ weight changes of broiler finisher.

\section{Subject Areas}

Agricultural Science

\section{Keywords}

Broiler, Cajanus cajan, Treatment, Replicate, Carcass, Organ

\section{Introduction}

In spite of the enormous natural and human resources at her disposal, Nigeria still remains amongst the least consumer of animal protein in Africa [1]. The current acute storage of animal protein in Nigeria and a rapidly increasing demand for livestock product could partly be alleviated through increasing animal production. The low protein intake had been attributed to low level of animal protein and high cost of animal product [2]. The demand for eggs and poultry meat has significantly increased in recent years across large parts of the continent due to the high population growth in Africa and growing income [3]. According to estimate by USAID (United States Agency for International Development), this trend is very likely to continue over the next few years. Therefore, the consumption of poultry meat and eggs will increase by 200\% between 2010 and 2020 for some countries in sub-Saharan Africa. The Nigeria poultry industry in particular has been rapidly expanding in recent years and is therefore one of the most commercialized subsectors of Nigeria agriculture [4].

Nutrition is the most important consideration in poultry industry and its survival is dependent on the availability of feedstuffs which are mainly component of human food e.g. soybean [5]. However, feed cost is presently very high and makes up $70 \%-80 \%$ of the total cost of production in Nigeria compared to $50 \%$ - 70\% in the developed countries [6]. This is partly due to increased population which has led to competition between human and animal for conventional plant protein sources such as soybean which has led to an increase in price of this ingredient. The pressure on this feedstuff (soybean) must therefore be reduced by 
exploiting alternative ones of adequate and even greater nutritional potential in or other to reduce the cost of farm animal production.

It is in light of the above that pigeon pea is considered for its feeding value. Pigeon pea (Cajanus cajan) is a tropical leguminous plant with high seeds and foliage yield. The legume is potentially suitable for feeding with a protein content ranging between $20.2 \%$ and $21.2 \%$.

However, the nutritive value of pigeon pea is masked by the occurrence of anti-nutritional factors such as tannins, trypsin inhibitors hydrogen cyanide, saponins and phytic acid [7].

Processing methods such as heating, soaking or fermentation can be used to reduce the anti-nutritional factors and improve the nutritional value and its by-products. Boiling, toasting and soaking are some of the processing methods which had been used [8] to inactivate these anti-nutritional factors.

\section{Materials and Methods}

\subsection{Experimental Site}

The experiment was carried out at the Teaching and Research Farm, Oyo State College of Agriculture and Technology Igboora, Oyo state in the derived Savannah zone of Nigeria. The College is located at $7^{\circ} 15 \mathrm{~N}$ and $303^{\circ} \mathrm{E}$ of the equator with average annual rain fall $1278 \mathrm{~mm}$ and average temperature of $27^{\circ} \mathrm{C}$.

Collection and processing of test ingredients: Pigeon pea was purchased from Towobowo market in Igboora. The raw pigeon pea seeds were soaked at the rate of $1 \mathrm{~kg} / 3 \mathrm{~L}$ of water for 12 hours. The soaked seeds were soaked at the rate of $1 \mathrm{~kg} / 3 \mathrm{~L}$ of raw pap water filtrate for 24 hours, initial and final $\mathrm{pH}$ were taken. The samples were sundried for 3 days, milled and then included in the diet accordingly.

\begin{tabular}{cc}
\hline $\mathrm{pH}$ range & CCSO \\
\hline Initial $\mathrm{pH}$ & 3.8 \\
Final $\mathrm{pH}$ & 4.6 \\
\hline
\end{tabular}

CCSO: Cajanus canjan soaked in ogi liquor.

\section{Anti-Nutrient Determination}

The test material raw and processed pigeon pea were analysed for anti-nutrient content such as oxalate, tannin, trypsin inhibitors, phytate and saponin.

\subsection{Experimental Diets}

A total of ninety birds were used for the study, they were randomly assigned into 3 dietary treatments of 30 birds consisting of 3 replicate often [9] birds per replicates in a completely randomized design experiment (Table 1).

Birds on $\mathrm{T} 1$ received the control diets; $\mathrm{T} 2$ received $10 \%$ level of pigeon pea, while T3 received 20\% level of pigeon pea. The experiment lasted for eight weeks. 
Table 1. Gross composition of experimental diets (\%).

\begin{tabular}{cccc}
\hline Ingredient & $\mathrm{T}_{1}(0 \%)$ & $\mathrm{T}_{2}(10 \%)$ & $\mathrm{T}_{3}(20)$ \\
\hline Maize & 60.00 & 60.00 & 60.00 \\
Soybean & 28.89 & 26.00 & 23.12 \\
Cajanus cajan & 0.00 & 2.89 & 5.77 \\
Bone meal & 4.00 & 4.00 & 4.00 \\
Lime stone & 6.11 & 6.11 & 6.11 \\
Lysine & 0.25 & 0.25 & 0.25 \\
Methionine & 0.25 & 0.25 & 0.25 \\
Salt & 0.25 & 0.25 & 0.25 \\
Broiler premix & 0.25 & 0.25 & 0.25 \\
Total & 100 & 100 & 100 \\
Crude Protein (\%) & 2840.43 & 2847.82 & 2855.20 \\
Metabolizable Energy (Kcal/kg) & 19.00 & 18.22 & 17.44 \\
\hline
\end{tabular}

A kg premix contains vitamin A; 110,000,000 i $\mu$ Vitamin D; 250,000 i $\mu$, Vitamin E; 20,000 mg Vitamin $\mathrm{K}_{3}$; $3000 \mathrm{mg}$, Vitamin $\mathrm{B}_{3} ; 3.00 \mathrm{mg}$ Vitamin $\mathrm{B}_{2} ; 7000 \mathrm{mg}$, Vitamin $\mathrm{B}_{6} ; 500 \mathrm{mg}$ Vitamin $\mathrm{B}_{12} ; 25 \mathrm{mg}$, Panthotenic acid; 10,000 mg, folic acid; $800 \mathrm{mg}$, Biotin; $50 \mathrm{mg}$ Manganese; 80,000 mg, Iron; $4000 \mathrm{mg}$, Zinc; 60,000 mg, Copper; $800 \mathrm{mg}$ Cobalt; $250 \mathrm{mg}$, Iodine; $1000 \mathrm{mg}$, Selenium (1\%); $150 \mathrm{mg}$, Chlorine, 200,000 mg and Anti oxidant; $10,000 \mathrm{mg}$.

\subsection{Data Collection}

\subsubsection{Carcass Yield}

At the end of the experiment which lasted for 8 weeks, three birds per replicate were selected from the treatment groups, they were weighed and slaughtered by severing the jugular vein, they were then thoroughly bled and scalded by dipping in warm water with temperature of $50^{\circ} \mathrm{C}-55^{\circ} \mathrm{C}$ before defeathering. The internal organs were removed. After evisceration, warm carcass was weighed immediately to determine the carcass yield. The weights of the carcass; breast, thigh, drumstick, back cut, wing were recorded individually. The weights of these selected parts were expressed as percentage of live weight of broilers, while the weight of selected organs; gizzard, liver, spleen, heart, proventriculus were recorded and expressed as a percentage of live weight.

\subsubsection{Chemical Analysis and Data Analysis}

Proximate composition of the experimental diets was determined according to the methods of AOAC 2003 [10]. All data analysed were done using SPSS version 20.0. The data were subjected to analysis of variance. Where treatment means were significant, separation of means was done using Duncans Multiple range test $[11]$ at $5 \%$ level of significance.

\section{Results}

Table 2 shows the proximate composition of pigeon pea soaked in pap water filtrate, the control diet had the highest value of crude protein $(20.75 \%)$ and ether extract (3.80\%) while the lowest value of crude protein (20.03\%) was observed for T3. Also, T3 recorded the highest value of ash (14.10\%) and dry matter 
$(92.70 \%)$

Table 3 shows the result of anti-nutritional factor content of raw and processed pigeon pea.

Table 4 shows the carcass characteristics of broiler finisher fed graded levels of acid soaked Cajanus cajan seed meal diets. The live weight, dress weight, pluged weight, dressing percentage, neck, wing, breast muscle, thigh, drum stick and shank were significantly $(\mathrm{P}<0.05)$ affected by dietary treatments, while there no significant $(\mathrm{P}>0.05)$ difference in the value recorded for head and back. However, birds on T2 recorded the highest value of live weight (2850.50\%), dress weight (2565\%), plucked weight (285.50\%), neck (5.00\%), back (11.59\%) while the lowest value of live weight was recorded for birds on T1 (2481.50\%), dress weight (2285\%), plucked weight (196.50\%). back (11.10\%). Broilers on T1 recorded the highest value of thigh (10.69\%), drum stick (10.94\%) and shank (5.14\%) while birds on T3 recorded the lowest value of thigh (10.04\%) and drum stick (10.59\%) with birds on T2 recording the lowest value of shank (4.44\%).

Table 5 showed the organ weight changes of broiler finisher fed graded levels of acid soaked Cajanus cajan based diet. The liver, lungs, spleen, kidney, bile, GIT weight, open gizzard, empty gizzard, proventriculus and GIT length were all influenced by dietary treatments $(\mathrm{P}<0.05)$ and there were no significant $(\mathrm{P}>$ $0.05)$ difference in live weight and heart. Birds on T2 had the highest value of liver (2.15\%), lungs (0.56\%), GIT weight (4.72\%) and GIT length (5.53\%) while birds on T3 had the lowest value of liver (1.84\%), lungs (0.37\%), GIT weight (4.01\%).

Table 2. Proximate composition of experimental animal diet.

\begin{tabular}{cccc}
\hline Parameters & T1 $(0 \%)$ & T2 (10\%) & T3 (20\%) \\
Crude protein & 20.75 & 20.21 & 20.03 \\
Ash & 10.70 & 8.10 & 14.10 \\
Crude fibre & 8.10 & 7.70 & 8.30 \\
Ether extract & 3.80 & 3.50 & 3.50 \\
Dry matter & 92.28 & 92.02 & 92.70 \\
\hline
\end{tabular}

Table 3. Anti-nutritional factor content of raw and processed pigeon pea.

\begin{tabular}{cccc}
\hline Anti-nutritional factors & Raw & Processed & Percentage reduction \\
\hline Tannin & 0.07 & 0.0052 & 27.71 \\
Oxalate & 0.0014 & 0.00055 & 60.7 \\
Phytate & 0.0028 & 0.0016 & 42.8 \\
Saponin & 0.00245 & 0.00180 & 26.5 \\
Trypsin inhibitors & 12.105 & 8.10 & 33.08 \\
\hline
\end{tabular}


Table 4. Carcass characteristics of broiler finisher fed graded levels of acid soaked $\mathrm{Ca}$ janus cajan seed meal diet.

\begin{tabular}{ccccc}
\hline Parameters & $\mathrm{T}_{1}(0 \%)$ & $\mathrm{T}_{2}(10 \%)$ & $\mathrm{T}_{3}(20 \%)$ & SEM \\
\hline $\begin{array}{c}\text { Live weight (g/bird) } \\
\text { Dressed weight } \\
\text { (g/bird) }\end{array}$ & $2481.50^{\mathrm{c}}$ & $2850.50^{\mathrm{a}}$ & $2721.00^{\mathrm{b}}$ & 88.25 \\
$\begin{array}{c}\text { Plucked weight } \\
\text { (g/bird) }\end{array}$ & $2285.00^{\mathrm{c}}$ & $2565.00^{\mathrm{a}}$ & $2501.50^{\mathrm{b}}$ & 69.20 \\
Dress (\%) & $196.50^{\mathrm{c}}$ & $285.50^{\mathrm{a}}$ & $219.50^{\mathrm{b}}$ & 21.78 \\
Head (\%) & $92.09^{\mathrm{a}}$ & $93.99^{\mathrm{c}}$ & $92.91^{\mathrm{b}}$ & 0.55 \\
Neck (\%) & 2.48 & 2.48 & 2.40 & 0.02 \\
Wing (\%) & $4.53^{\mathrm{b}}$ & $5.00^{\mathrm{a}}$ & $3.93^{\mathrm{c}}$ & 0.25 \\
Breast muscle (\%) & $9.02^{\mathrm{a}}$ & $8.53^{\mathrm{c}}$ & $8.99^{\mathrm{b}}$ & 0.13 \\
Back (\%) & $28.20^{\mathrm{b}}$ & $25.74^{\mathrm{c}}$ & $29.24^{\mathrm{a}}$ & 0.85 \\
Thigh (\%) & 11.10 & 11.59 & 11.44 & 0.12 \\
Drum stick (\%) & $10.69^{\mathrm{a}}$ & $10.47^{\mathrm{ab}}$ & $10.04^{\mathrm{c}}$ & 0.16 \\
Shank (\%) & $10.94^{\mathrm{a}}$ & $10.93^{\mathrm{a}}$ & $10.59^{\mathrm{b}}$ & 0.09 \\
\hline
\end{tabular}

a, b, c: Means within the same row with the different superscript are significantly $(\mathrm{P}<0.05)$ difference, S.E.M: Standard error of mean.

Table 5. Organ changes of broiler finisher fed graded levels of acid soaked Cajanus cajan seed meal diet.

\begin{tabular}{ccccc}
\hline Parameters & T1 & T2 & T3 & SEM \pm \\
\hline Live Weight & 1624 & 1533.67 & 1542 & 0.02 \\
Heart & 0.58 & 0.57 & 0.43 & 0.05 \\
Liver & $1.85^{\mathrm{b}}$ & $1.15^{\mathrm{a}}$ & $1.84^{\mathrm{bc}}$ & 0.08 \\
Lungs & $0.40^{\mathrm{bc}}$ & $0.46^{\mathrm{b}}$ & $0.37^{\mathrm{a}}$ & 0.05 \\
Spleens & $0.04^{\mathrm{b}}$ & $0.02^{\mathrm{c}}$ & $0.08^{\mathrm{a}}$ & 0.01 \\
Kidney & $0.41^{\mathrm{b}}$ & $0.41^{\mathrm{b}}$ & $0.43^{\mathrm{a}}$ & 5.44 \\
Bile & $0.20^{\mathrm{a}}$ & $0.13^{\mathrm{b}}$ & $0.17^{\mathrm{ab}}$ & 0.02 \\
Git Weight & $4.42^{\mathrm{b}}$ & $4.72^{\mathrm{a}}$ & $4.01^{\mathrm{c}}$ & 0.17 \\
Git Length & $5.09^{\mathrm{c}}$ & $5.53^{\mathrm{a}}$ & $5.30^{\mathrm{b}}$ & 0.10 \\
Open Gizzard & $2.49^{\mathrm{c}}$ & $3.03^{\mathrm{a}}$ & $2.94^{\mathrm{b}}$ & 0.14 \\
Empty Gizzard & $1.57^{\mathrm{c}}$ & $2.18^{\mathrm{ab}}$ & $2.20^{\mathrm{a}}$ & 0.17 \\
Proventiculus & $0.43^{\mathrm{c}}$ & $0.49^{\mathrm{b}}$ & $0.61^{\mathrm{a}}$ & 0.04 \\
\hline
\end{tabular}

a, b, c: Means within the same row with the different superscript are significantly $(\mathrm{P}<0.05)$ difference, S.E.M: Standard error of mean.

\section{Discussion}

1) Carcass: The effect of processed pigeon pea on carcass characteristics of broiler chicken significantly $(\mathrm{P}<0.05)$ influenced live weight, dressed weight, 
plucked weight, dress percentage, head, neck wing, breast muscle, back, thigh, drum stick and shank. Values obtained for the live weight dressed weight, plugged weightdress percentage for birds on tested diet was significantly higher than those control diet. Feeding of pigeon pea at $10 \%$ and $20 \%$ level of inclusion showed better utilization of the seed by birds. Birds were able to utilize the nutrients in the feed and convert into flesh at both $10 \%$ and $20 \%$ inclusion levels. This might be due to the level of anti-nutritional factors present at this inclusion level was minimal and does not have much negative effect on the carcass yield of the birds. The increment noticed could be traced to better utilization of the nutrients in the diet and good amino acid profile of the diet.

This result of this research also suggested that the lower the inclusion level the higher the availability of nutrients which could be seen in the values obtained for live weight, dressed weight and dress percentage. Hence processing methods do not completely eliminate traces of ANFs. The result confirms the findings of [12] who observed that most processing methods employed at improving the feeding values of non-conventional legumes do not completely eliminate ANF but only reduce their concentration to tolerable level in feed.

2) Organ changes: Increase in weight of organs of broilers can be linked to the presence of antinutritional factors. It can be submitted that enlargement of the heart muscles was not a consistent change in birds fed velvet beans, if it does the author asserted it may represent extra work load impose by stress or disease. The lower value of liver for birds on T2 and T3 when compared with those on control could mean that the residual anti-nutritional factors present in the pigeon pea do not cause abnormal size of the organ which is an organ of biotransformation in animals [13] identifies these organs as the primary organ of biotransformation and linked the changes in the organ to its role in elimination of toxins from the animal body. Also, the higher value of GIT length, open gizzard, empty gizzard and proventriculus for birds on T2 and T3 when compared with the control may not be linked to the presence of ANFs. The differences could have been due to the differences in the growth of anatomical parts of the animal.

Birds on T3 have the highest value of kidney compared to birds on T1 and T2 which could be attributed to the effect of residual ANF. The kidney is a detoxifying organ hence enlargement and increase in weight is as a result of increase in activity of the organ to detoxify residual ANF. [9] reported an increase in the weight of the kidney fed raw lima bean and this was attributed to the fact that key enzyme in cyanide detoxification (Rhodanase) is the kidney therefore increase muscular activities of the kidney might lead to an increase.

\section{Conclusion}

It could be concluded that pigeon pea soaked in acidic medium can be fed to birds at $20 \%$ level of inclusion without any negative effect on the organ weight of broiler finisher fed experimental diet. 


\section{Recommendation}

Feeding up to $20 \%$ level of inclusion showed good results, further experiment can be conducted and the level of inclusion can be increased to $40 \%$.

\section{Conflicts of Interest}

The authors declare no conflicts of interest regarding the publication of this paper.

\section{References}

[1] Lamorde, A.G. (1998) Building for Nigeria Livestock Industry in the $21^{\text {st }}$ Century. Proceedings of 3 rd Annual Conference of the Animal Science Association of Nigeria, Abeokuta, 21-26 March 1998.

[2] Ani, A.O. and Adiegwu, L.L. (2005) The Feeding Value of Velvet Bean (Mucunaprupriena) to Weaner Rabbits. Proceedings of 30th Annual Conference of Nigeria Society for Animal Production, Nsukka, Nigeria, 20-24 March 2005, 186-189.

[3] World Health Organization (2014) African Region: Nigeria. http://www.int/countries/nga/en

[4] Adene, D.F. and Oguntade, A.E. (2006) The Structure and Importance the Commercial and Village Based Poultry System in Nigeria. FAO, United States Department of Agriculture. International Egg and Poultry Report.

[5] Esonu, B.O. (2000) Animal Nutrition and Feeding: A Functional Approach. Rukzeal and Rukson Association Memory Press, Owerri, Nigeria.

[6] Thackie, A.M. and Flenscher. J.E. (1995) Nutritive Value of Wild Sorghum Fortified with Leucaena (Leucaena leucocephala Wh. Lam). Bulletin of Animal Health and Production in Africa, 43, 223-275.

[7] Akinmutimi, A.H., Aligwara, O.A. and Abasiekong, S.F. (2008) The Effect of Qutitative Replacement of Soya Bean Meal with Cooked and Toasted Lima Bean Meal on Growth Performance and Carcass Quality Value of Broiler Finisher Birds. International Journal of Poultry Science, 7, 487-490.

[8] Ahmaefule, K.U. and Obioha, F.C. (1998) The Substitution of Pigeon Pea Seed (Cajanus cajan) for Groundnut Cake and Maize in Broilers Finisher Ration. Nigerian Journal of Animal Production, 25, 9-12. https://doi.org/10.51791/njap.v25i1.2175

[9] Ologbogo, A.D., Apata, D.F.M. and Oyejide, A. (1993) Utilization of Raw Jack Bean Canavaliaensiformis and Jack Bean Fractions in Diets for Broiler Chicks. British Poultry Science, 34, 323-337. https://doi.org/10.1080/00071669308417588

[10] AOAC International (2003) Official Methods of Analysis of AOAC International. Official Method 945.18. Cereals Adjuncts, 17th ed. 2nd rev. Gaithersburg, MD.

[11] Duncan, D.B. (1995) Multiple Range and Multiple F Test. Biometrics, 11, 1-4. https://doi.org/10.2307/3001478

[12] Akinmutimi, A.H. (2004) Evaluation of Sword Bean (Canavalia gladiata) as an Alternative Feed Resources for Broiler Chicken. Ph.D. Thesis, Micheal Okpara University of Agriculture Umudike, Nigeria.

[13] Onyeyili, P.A., Iwoha, E.I. and Akinniyi, J.A. (1998) Chronic Toxicity Study of Fiscusplatyphyila Blume in Rat. West African Journal of Pharmacology, Drug Research, 14, 27-30. 